\title{
E-VILLAGE BUDGETING : EFEKTIVITAS PENCEGAHAN FRAUD PADA PENGELOLAAN KEUANGAN DESA DI KABUPATEN BANYUWANGI
}

\author{
Anak Agung Gde Satia Utama \\ Airlangga University \\ gde.agung@feb.unair.ac.id \\ Afika Rana Zahari \\ Airlangga University \\ afikarana@feb.unair.ac.id
}

\begin{abstract}
This study aims to examine whether the current village financial management system in Banyuwangi that uses E-Village Budgeting has been effective in preventing the possibility of fraud in managing village finances. The theories construct these researches are the fraud triangle theory, the fraud management process and ISO 9126. This study used qualitative exploratory methods. This study used the most common data analysis techniques, Max Weber's ideal type. This type is a model or mental abstraction of relationships or social processes. The typical variety is a clear standard where data or "reality" can compare. EVB effectiveness testing is done using ISO 9126. The result of this study is the village government feels that the current EVB system has been effective in preventing fraud in village financial management. This is because EVB has a different mechanism than when it is still manual, in the process of disbursing funds. This research can be used as a basis for further research on EVB and can be an input for the Banyuwangi government in taking additional EVB development policies.
\end{abstract}

Keywords: Electronic Village Budgeting, fraud, ISO 9126, village financial management

PENDAHULUAN

Undang-Undang Nomor 23 Tahun 2014 tentang Pemerintah Daerah menyebutkan bahwa dalam rangka peningkatan kinerja penyelenggaraan pemerintah daerah, Pemerintah Daerah dapat melakukan inovasi. Inovasi adalah semua bentuk pembaharuan dalam penyelenggaraan pemerintahan daerah. Inovasi diperlukan pemerintah daerah sebagai langkah yang strategis perbaikan penyelenggaraan pemerintahan daerah yang baik dan bersih (Pratiwi, 2016). Salah satu bentuk inovasi dalam pengelolaan keuangan dana desa adalah dengan dimasukannya unsur kecanggihan teknologi dalam kegiatan-kegiatan operasional pengelolaan keuangan.

Penggunaan instrumen teknologi informasi sebagai pilar pendukung pelayanan publik terus dipacu Pemerintah Kabupaten Banyuwangi hingga ke pemerintahan desa. Bentuk penggunaan instrumen teknologi dalam peningkatan pelayanan publik ini adalah dengan diterapkannya program E-Village Budgeting (EVB). Program EVB Pemerintah Kabupaten Banyuwangi mendapatkan penghargaan Top 40 dalam Kompetisi Inovasi Pelayanan Publik (Sinovik) dari Kementerian 
Pendayagunaan Aparatur Negara dan Reformasi Birokrasi (Menpan-RB) tahun 2017 (banyuwangikab.go.id). EVB mendapatkan penghargaan tersebut karena telah berhasil memenuhi kriteria-kriteria inovasi pelayanan publik yaitu memperkenalkan pendekatan baru, produktif, berdampak, dan berkelanjutan.

Dikutip dari website resmi banyuwangikab.go.id, pada 28 Agustus 2017, Bupati Banyuwangi Abdullah Azwar Anas menyampaikan bahwa, e-Village Budgeting adalah program untuk menuju transparansi penganggaran dan monitoring pembangunan di pelosok desa. Sistem ini ke depan akan menyinergikan keuangan dan pembangunan di tingkat desa dan kabupaten, sehingga tercipta keselarasan. Sistem ini sekaligus memberi perlindungan bagi perangkat desa agar dalam pemanfaatan anggarannya bisa efektif dan sesuai aturan. E-Village Budgeting di Banyuwangi terdiri atas tiga bagian, yaitu perencanaan, tata kelola, dan evaluasi. Sistem ini memangkas mata rantai penyusunan anggaran secara manual di level desa. Melalui cara ini, pencairan anggaran juga mudah terpantau. Setiap dana yang turun akan langsung disinkronkan. Kegiatan yang ada juga tersusun rapi sesuai rencana dan anggaran. Selain E-Village Budgeting di Kabupaten Banyuwangi, penerapan inovasi pengelolaan keuangan desa berupa aplikasi sistem keuangan desa atau SISKEUDES dilakukan diberbagai daerah berdasarkan nota kesepahaman anatara Menteri Dalam Negeri bersama Kepala Badan Pengawasan Keuangan Pembangunan Nomor 9001627115J dan MOU-16/I(D412015) tentang pengelolaan keuangan desa.

Tabel 1

Total Besaran DD dan ADD yang Diterima Setiap Desa di Kabupaten Banyuwangi Tahun 2015-2018

\begin{tabular}{cccccc}
\hline \multirow{2}{*}{ No } & \multirow{2}{*}{ Sumber Dana } & \multicolumn{4}{c}{ Tahun Anggaran (Rp) (dalam Jutaan) } \\
\cline { 3 - 6 } & & 2015 & 2016 & 2017 & 2018 \\
\hline 1 & Dana Desa & $59.888,61$ & - & $172.183,36$ & $167.707,41$ \\
\hline 2 & Alokasi Dana Desa & $61.900,00$ & $83.018,36$ & $148.638,00$ & $148.638,00$ \\
\hline
\end{tabular}

Sumber : Data Olahan, 2018

Berdasarkan data diatas, dana yang diturunkan untuk desa tiap tahun tergolong besar. Hasil wawancara dengan Dinas
Pemberdayaan Masyarakat dan Desa yang telah dilakukan pada 15 Oktober 2018, pada tahun 2017 ke 2018 terjadi penurunan 
besaran dana desa yang diterima Pemkab Banyuwangi dari tahun 2017 ke 2018. Penurunan ini murni dikarenakan kebijakan dari pemerintah pusat sendiri berdasarkan hasil evaluasi yang telah mereka lakukan. Namun walaupun terjadi penurunan, angka yang diterima masih tergolong besar. Besarnya dana yang harus dikelola desa saat ini, membuat proses pengelolaan keuangan menjadi semakin kompleks. Dan jumlah dana yang besar tersebut membuat peluang terjadinya kecurangan semakin besar. Diperlukan suatu mekanisme system pengelolaan keuangan yang mampu menjalankan fungsi controlling and monitoring dengan baik. Oleh karena itu, penelitian ini ingin mengeksplorasi lebih dalam sistem pengelolaan keuangan desa di Kabupaten Banyuwangi saat ini yang menggunakan E-Village Budgeting telah efektif dalam mencegah kemungkinan adanya kecurangan dalam pengelolaan keuangan desa. Untuk menjawab hal tersebut disusun pertanyaan-pertanyaan penelitian seperti : bagaimana pelaksanaan EVB di Kabupaten Banyuwangi?, bagaimana pengelolaan keuangan desa yang telah dilakukan oleh perangkat desa?, bagaimana EVB dapat mencegah terjadinya penyalahgunaan keuangan desa?, dan apakah sistem informasi EVB yang diterapkan pemerintah kabupaten Banyuwangi saat ini sudah memadai?
Adapun tujuan yang ingin dicapai oleh penelitian ini yaitu untuk mengetahui dan mengevaluasi Sistem Informasi E-Village Budgeting yang diterapkan oleh desa-desa di Kabupaten Banyuwangi serta mengevaluasi peran E-Village Budgeting dalam pencegahan fraud pengelolaan keuangan desa di Kabupaten Banyuwangi.

\section{KAJIAN TEORITIK Teori Sistem Informasi}

The term information system suggests the use of information technology (IT) in an organization to provide information to users. A computer-based information system is a collection of computer hardware and software designed to transform data into useful information (Bodnar, 2013).

Menurut Gelinas (2008 : 13), sistem informasi merupakan sistem yang dibuat oleh manusia yang secara umum terdiri dari seperangkat komponen berbasis komputer dan manual yang terintegrasi, dibuat untuk mengumpulkan, menyimpan dan mengelola data dan menyediakan keluaran berupa informasi kepada pengguna.

Sistem informasi memfasilitasi fungsi operasional dan mendukung pengambilan keputusan manajemen dengan menyediakan informasi yang dapat digunakan manajer untuk merencanakan dan mengendalikan aktivitas perusahaan (Gelinas : 2008). 
Teori Segitiga Kecurangan

Kecurangan (fraud) didefinisikan sebagai kesalahan atau tindakan criminal yang bertujuan untuk memperoleh keuntungan finansial atau pribadi (Attigeri et al., 2018). Berdasarkan teori segitiga kecurangan, ada tiga faktor yang memicu seseorang untuk melakukan kecurangan yaitu tekanan, kesempatan dan rasionalisasi. Cressey (1953) dalam Lokanan (2015), berhipotesis bahwa individu melakukan kecurangan karena tekanan keuangan yang tidak ingin dia bagikan. Tekanan keuangan yang tidak dibagikan adalah ketegangan keuangan yang dialami seorang individu, dimana ia tidak ingin membaginya dengan orang lain. Ketidakmampuan individu untuk mengkomunikasikan ketegangan keuangan berfungsi sebagai motivasi untuk melanggar hukum untuk memecahkan masalah. Dari penjelasan tersebut dapat disimpulkan juga bahwa teori segitiga kecurangan memfokuskan perhatiannya pada kerapuhan moral individu dan menetapkan tugas organisasi dalam mengawasi individu yang beresiko

(Morales et al., 2014).

Peluang untuk melakukan penipuan adalah komponen selanjutnya dari segitiga kecurangan Cressey (1953) dalam Lokanan (2015). Kesempatan yang dirasakan untuk melakukan tindakan kecurangan muncul ketika seseorang dalam posisi kepercayaan melanggar kepercayaan itu untuk mengatasi tekanan keuangan yang tak dapat dibagi (Cressey, 1953:30).

Rasionalisasi adalah kurangnya perasaan dan ketidakpedulian yang diungkapkan oleh pelanggar untuk membenarkan setiap kesalahan yang timbul dari kesalahan mereka (Dellaportas, 2013 : 32) dalam Lokanan (2015). Ini adalah mekanisme di mana seorang karyawan menentukan bahwa perilaku curang itu "baik" dalam pikirannya.

\section{The Fraud Management Process}

Salah satu risiko yang dihadapi organisasi yang dapat memengaruhi pencapaian tujuan adalah risiko kecurangan (fraud risk) (Rubasundram, 2015). Manajemen kecurangan (fraud) adalah proses yang melibatkan beberapa fase yang terkait erat : pencegahan, deteksi, investigasi, pelaporan, dan litigasi dan pemulihan. Akuntan yang mengkhususkan diri dalam bidang kecurangan, secara rutin melakukan layanan di semua fase proses manajemen kecurangan ini (Bodnar, 2013 : 150).

\section{Pencegahan Fraud (Fraud Prevention)}

Menurut Bodnar (2013), pada tingkat yang paling dasar, pencegahan fraud dalam organisasi adalah masalah pengendalian internal yang baik. Namun, karena kompleksitas teknologi informasi yang terus meningkat, penerapan pengendalian 
internal sekarang membutuhkan sistem manajemen keamanan informasi khusus (ISMS). Sistem semacam itu memiliki tiga tujuan umum antara lain, kerahasiaan dimana data hanya tersedia untuk orang yang berwenang, lalu integritas dimana data harus akurat dan lengkap serta ketersediaan yaitu data tersedia kapan dan di mana diperlukan. Sedangkan hasil penelitian menurut Rahman dan Anwar (2014), komponen paling efektif dalam pencegahan fraud di sebuah organisasi adalah adanya perangkat lunak atau aplikasi yang terproteksi dengan baik.

Pencegahan fraud adalah bagian dari proses Enterprise Risk Management (ERM). Dengan demikian, pencegahan tidak pernah mutlak tetapi hanya relatif terhadap risiko masing-masing organisasi. Oleh karena itu, pencegahan adalah masalah tingkat, sehingga analisis biayamanfaat yang cermat selalu menghasilkan ISMS yang menyimpan beberapa risiko kecurangan.

Pencegahan kecurangan yang optimal membutuhkan lebih dari sekadar menerapkan daftar periksa kontrol yang berisi item seperti firewall, perangkat lunak anti-virus, dan sebagainya. Sebaliknya, diperlukan pendekatan siklus hidup yang sistematis yang dimulai dengan ancaman dan kerentanan dan diakhiri dengan menerapkan kontrol berbasis risiko yang sesuai. Prosesnya sangat rumit sehingga badan-badan berwenang telah mengumumkan berbagai standar dan kerangka kerja untuk ISMS.

\section{Deteksi Fraud (Fraud Detection)}

Deteksi fraud adalah bagian dari sekelompok proses yang lebih besar yang meliputi pencegahan fraud, investigasi, koreksi, pelaporan dan pemulihan. Tidak satupun dari proses ini berjalan sendiri. Banyaknya sumber daya yang harus disediakan untuk satu proses individu memengaruhi kebutuhan penyediaan sumber daya bagi proses yang lain. Sebagai contoh, pencegahan yang baik akan mengarah pada sedikitnya fraud yang terjadi, dimana hal ini akan menghasilkan lebih sedikit fraud yang terdeteksi, sehingga proses investigasi yang harus dilakukan pun akan berkurang (Bodnar, 2013).

Deteksi fraud meliputi identifikasi indikator kecurangan yang nantinya mengarah menuju investigasi lebih lanjut. Indikator kecurangan dapat berupa indikator individual (misalnya red flags) atau indikator gabungan. Red flags meliputi kejadian-kejadian seperti ketidaksesuaian dalam penghitungan persediaan, register kas yang tidak balance, tagihan yang mencurigakan, dan lainnya. Indikator gabungan secara khusus berdasarkan pada kombinasi beberapa indikator individual yangmana ketika tampak sekali mungkin

59 E-VILLAGE BUDGETING : EFEKTIVITAS PENCEGAHAN FRAUD PADA PENGELOLAAN KEUANGAN DESA DI KABUPATEN 
belum bisa dijadikan tanda adanya fraud. Indikator gabungan terkadangdisebut juga risk scores (Bodnar, 2013).

Untuk mengurangi kemungkinan terjadinya fraud, dapat dilakukan beberapa metode untuk mendeteksi fraud secara lebih dini. Salah satunya adalah merancang model pembelajaran mesin yang akurat untuk meningkatkan pemantauan penggunaan layanan, sehingga fraud dapat segera dideteksi dan untuk selanjutnya ditindaklanjuti (Chouiekh dan El Haj, 2018). Berikut beberapa metode untuk mendeteksi fraud yang lain menurut Romney dan Steinbart (2017)

\section{Tabel 2}

\section{Fraud Detection Methods}

Mengembangkan dan mengimplementasikan program penilaian resiko kecurangan yang mengevaluasi baik kemungkinan maupun besarnya aktivitas kecurangan dan menilai proses dan pengendalian yang dapat mencegah dan mendeteksi potensi kecurangan

Membuat sebuah riwayat audit sehingga transaksi individual dapat di telusuri melalui system ke laporan keuangan dan data laporan keuangan dapat ditelusuri kembali ke transaksi individual

Menghubungkan periode audit internal dan eksternal, begitu juga jaringan keamanan khusus audit, hal ini dapat secara khusus membantu jika suatu saat audit dilakukan dalam keadaan tak terduga

\begin{tabular}{c}
\hline Memasang perangkat lunak deteksi kecurangan \\
\hline Mengimplementasikan hotline kecurangan \\
\hline Memotivasi pegawai untuk melaporkan kecurangan dengan \\
mengimplementasikan hadiah dan perlindungan bagi whistleblower yang datang \\
\hline Mempekerjakan petugas keamanan computer, konsultan computer dan spesialis \\
forensic sesuai kebutuhan \\
\hline Memantau aktivitas system, termasuk jaringan dan keamanan, penggunaan dan \\
kesalahan, dan tindakan berbahaya. Gunakan system pendeteksi intrusi untuk \\
membantu mengotomasi proses pemantauan
\end{tabular}

Sumber : Romney and Steinbart, 2017 
Pengujian efektivitas sebuah system tentu membutuhkan tolok ukur. Salah satu tolok ukur yang dapat digunakan adalah ISO 9126. ISO 9126 merupakan sebuah standar untuk mengukur kualitas suatu perangkat lunak yang dibuat oleh International Organization for Standardization (ISO) dan International Electrotechnical Commission (IEC). ISO 9126 mendefinisikan karakteristik mutu, kualitas produk perangkat lunak, model dan metric terkait untuk mengevaluasi dan menetapkan kualitas sebuah produk perangkat lunak. Berdasarkan penelitian yang telah dilakukan Ayu (2018), ISO 9126 memiliki kelebihan yaitu dapat memberikan pengukuran dari sisi internal dan eksternal sebuah perangkat lunak. Selain itu ISO 9126 lebih adaptable yang dapat digunakan untuk keseluruhan system sehingga dapat mendeteksi kesalahan potensial, mengevaluasi efektivitas dan kualitas perangkat lunak (Sukoco, 2010). Tabel 2.3 berikut menjelaskan enam karakteristik dari model kualitas perangkat lunak menurut ISO 9126 :

Tabel 3

Karakteristik Kualitas Perangkat Lunak Menurut ISO 9126

\begin{tabular}{|c|c|c|}
\hline No & Karakteristik & Definisi \\
\hline 1 & Functionality & $\begin{array}{l}\text { Kemampuan dari segi fungsi } \\
\text { produk perangkat lunak yang } \\
\text { menyediakan kepuasan }\end{array}$ \\
\hline 2 & Reliability & $\begin{array}{l}\text { Kemampuan perangkat lunak untuk } \\
\text { perawatan dengan level } \\
\text { performansi }\end{array}$ \\
\hline 3 & Usability & $\begin{array}{l}\text { Atribut yang menunjukkan tingkat } \\
\text { kemudahan pengoperasian } \\
\text { perangkat lunak }\end{array}$ \\
\hline 4 & Efisiensi & $\begin{array}{l}\text { Menyangkut waktu eksekusi dan } \\
\text { kemampuan yang berhubungan } \\
\text { dengan sumber daya fisik yang } \\
\text { digunakan ketika perangkat lunak } \\
\text { dijalankan }\end{array}$ \\
\hline 5 & Maintanability & $\begin{array}{ccr}\text { Tingkat } & \text { kemudahan } & \text { perangkat } \\
\text { lunak } & \text { tersebut } & \text { dalam }\end{array}$ \\
\hline
\end{tabular}




\begin{tabular}{lll}
\hline & $\begin{array}{l}\text { mengakomodasi perubahan- } \\
\text { perubahan }\end{array}$ \\
\hline $6 \quad$ Portabiity & Kemampuan yang berhubungan \\
& dengan kemampuan perangkat \\
& lunak yang dikirim ke lingkungan \\
& berbeda \\
\hline
\end{tabular}

\section{Sumber : ISO 9126, 2009}

\section{Penelitian Terdahulu}

Penelitian sebelumnya dilakukan oleh Supanji Setyawan, Nuwun Priyono, dan Chaidir Iswanaji pada tahun 2017 dengan judul Development Model of E-Budgeting and E-Reporting System on the Management of Village Fund Finance. Penelitian ini bertujuan untuk menganalisis kemampuan desa dalam melaksanakan manajemen dana desa dan kemudian mengembangkan sistem e-budgeting dan ereporting untuk realisasi efisiensi alokasi dana desa di Desa Balesari. Metode penelitian yang digunakan adalah metode kualitatif dengan model studi kasus. Hasil penelitian menunjukkan bahwa penyusunan e-budgeting dalam kegiatan penganggaran Pemkab Magelang telah membantu merefleksikan realisasi dana desa, yaitu dengan membuat proses kegiatan anggaran, mulai dari perencanaan, penganggaran hingga pengendalian anggaran menjadi lebih cepat dan dapat mengurangi biaya yang dikeluarkan oleh Pemerintah Desa Balesari dalam mencapai realisasi anggaran.
Penelitian selanjutnya dilakukan oleh Munfarida dkk pada tahun 2018 dengan judul Pengelolaan Keuangan Desa Melalui E-Village Budgeting di Kabupaten Banyuwangi. Penelitian membahas tentang pengelolaan keuangan desa melalui aplikasi untuk desa. Penelitian ini bertujuan untuk menentukan manajemen keuangan desa di Desa Srono, Kabupaten Banyuwangi dengan menggunakan sistem EVB dan efektivitas penggunaan sistem tersebut. Metode analisis data menggunakan pendekatan kualitatif deskriptif dan triangulasi untuk menguji validitas data. Hasil penelitian menunjukkan manajemen keuangan desa menggunakan EVB terdiri dari tiga proses yaitu perencanaan, administrasi dan akuntabilitas APBDesa. Dengan menggunakan EVB manajemen keuangan desa menjadi lebih efektif dan efisien.

\section{METODE PENELITIAN Pendekatan Penelitian}

Penelitian ini menggunakan pendekatan kualitatif deskriptif. Menurut Neuman (2014 : 34), pendekatan ini digunakan jika 
kita ingin mendeskripsikan suatu fenomena sosial. Penelitian deskriptif menyajikan gambaran detail spesifik dari situasi, pengaturan sosial, atau hubungan. Penelitian deskriptif dimulai dengan masalah atau pertanyaan yang terdefinisi dengan baik dan mencoba untuk menggambarkannya secara akurat. Hasil penelitian adalah gambaran rinci tentang masalah atau jawaban atas pertanyaan penelitian. Peneliti deskriptif menggunakan sebagian besar teknik pengumpulan data: survei, penelitian lapangan, analisis konten, dan penelitian komparatif historis. Berdasarkan hal tersebut penelitian ini akan memberikan deskripsi lengkap mengenai sistem informasi E-Village Budgeting dalam mencegah adanya fraud pengelolaan dana desa di Kabupaten Banyuwangi.

Penelitian kualitatif ini menggunakan metode studi kasus dalam mengevaluasi efektivitas EVB dalam mencegah adanya penyalahgunaan dana desa. Metode studi kasus secara intensif menyelidiki satu atau sejumlah kecil kasus, dengan berfokus pada banyak detail dalam setiap kasus dan konteksnya. Metode ini memperjelas pemikiran kita dan memungkinkan kita untuk menghubungkan ide-ide abstrak dengan cara-cara spesifik dengan kekhasan spesifik dari kasus-kasus yang kita amati secara terperinci (Neuman, 2014).

\section{Ruang Lingkup Penelitian}

Penelitian ini dibatasi ruang lingkup yang menjadi fokus penelitian, yakni sebagai berikut :

1. Penelitian dilakukan di DPMD, BPKAD, Diskominfo, Inspektorat dan empat desa di Kabupaten Banyuwangi.

2. Penelitian hanya difokuskan pada seberapa efektif sistem E-Village Budgeting yang diterapkan saat ini dalam mencegah terjadinya fraud pengelolaan keuangan desa di Kabupaten Banyuwangi.

\section{Jenis dan Sumber Data}

Data yang digunkan dalam penelitian ini terdiri dari 2 jenis data yaitu :

1. Data primer. Diperoleh langsung dari riset lapangan berupa hasil wawancara dengan beberapa komponen yang berperan penting dengan pengelolaan dana desa melalui EVB yang terdiri dari pemerintah kabupaten dan pemerintah desa.

2. Data sekunder. Data sekunder terdiri dari beberapa data terkait yang sudah ada yaitu, dokumen-dokumen atau arsip peraturan berkaitan dengan penerapan EVB dalam pengelolaan dana desa baik kebijakan yang dibuat atau disusun dari tingkat pemerintah kabupaten maupun pemerintah desa.

\section{Subjek Penelitian}

Prosedur pengumpulan data merupakan cara yang digunakan peneliti 
untuk mendapatkan data dalam suatu penelitian. Menurut Creswell (2014:189), untuk mendapatkan informasi prosedur pengumpulan data terdapat 4 tipe dasar yaitu qualitative observation, qualitative interview? <<ini peneliti menggunakan keempat prosedur tersebut dalam mendapatkan data yang dibutuhkan untuk menarik sebuah kesimpulan yang berhubungan dengan efektivitas sistem informasi EVB dalam mencegah fraud, yaitu :

Subjek dari penelitian ini adalah pemerintah kabupaten Banyuwangi dan pemerintah desa di kabupaten Banyuwangi.

Bagian dari pemerintah kabupaten Banyuwangi yang menjadi subjek penelitian ini adalah BPKAD, DPMD, Diskominfo dan Inspektorat. Sedangkan pemerintah desa yang menjadi subjek penelitian ini adalah desa di kabupaten Banyuwangi yang telah menerapkan EVB.

\section{Prosedur Pengumpulan Data}

1. Qualitative Observation, melakukan pengamatan langsung terhadap objek penelitian baik terlibat secara langsung maupun tidak langsung dalam berbagai aktivitas yang dilakukan.

2. Qualitative Interviews, dengan menyampaikan serentetan pertanyaan kepada informan terkait peran EVB dalam mencegah penyalahgunaan dana desa untuk memperoleh informasi.
3. Qualitative Documents, menurut Creswell (2014:190) terdapat dua tipe dokumen yang digunakan yaitu dokumen publik dan private. Dokumen publik, peneliti mencoba mengumpulkan informasi melalui artikel, kebijkan dan peraturan pemerintah. Sedangkan dokumen private, peneliti mencari jurnal pendukung dari penelitian yang lainnya untuk memperkuat informasi dalam penelitian yang saat ini dilakukan dan membandingkan penelitian saat ini dan sebelumnya.

4. Qualitative Audio and Visual Materials, prosedur terakhir yang dilakukan dengan mendapatkan data melalui foto, objek seni, video, website, email, text massages, social media text atau audio yang lainnya ( Creswell, 2014:190). Bagian ini peneliti menggunakan dokumen yang berasal dari informasi website yang bersumber dari objek penelitian, baik dari pihak desa maupun berasal dari pemerintah Kabupaten Banyuwangi.

\section{Teknik Analisis Data}

Menurut Neuman (2014 : 487), terdapat tujuh strategi yang dapat digunakan untuk menganalisis data kualitatif yaitu : ideal type, successive approximation, illustrative method, domain 
analysis, analytic comparison, narrative analysis, dan negative case method.

Pada penelitian ini digunakan metode yang paling umum yaitu Max Weber's ideal type. Tipe ini adalah model atau abstraksi mental dari hubungan atau proses sosial. Tipe ideal adalah standar murni dimana data atau "realitas" dapat dibandingkan. Tipe ideal ini adalah alat buatan yang digunakan untuk membandingkan karena tidak ada realitas yang cocok dengan tipe ideal.

\section{HASIL DAN PEMBAHASAN Gambaran Umum Subjek Penelitian}

Subjek dari penelitian ini adalah dinasdinas yang terkait dengan pengelolaan keuangan desa di kabupaten Banyuwangi yaitu Dinas Pengembangan Masyarakat dan Desa (DPMD) yang memiliki fungsi sebagai pembina dan pelaksana tugas di bidang pemberdayaan masyarakat dan pemerintahan desa, Badan Pengelolaan Keuangan dan Aset Daerah (BPKAD) dengan fungsi memantau, mengevaluasi, dan melaporkan pelaksanaan tugas dukungan teknis di bidang pengelolaan keuangan dan aset daerah, Inspektorat yang berperan sebagai auditor, serta Dinas Komunikasi, Informatika dan Persandian sebagai penyedia sistem EVB. Selain keempat dinas tersebut, terdapat empat desa terpilih di Kabupaten Banyuwangi yang juga menjadi objek penelitian. Desa tersebut adalah desa Cluring, Alasmalang, Ketapang dan Kedayunan. Keempat desa tersebut dipilih berdasarkan rekomendasi desa-desa yang dinilai cukup baik oleh BPKAD.

Gambaran Umum Penggunaan EVB Saat Ini

Dalam upaya pengembangan desa, halhal yang perlu diperhatikan tidak hanya penyediaan barang-barang publik tapi juga peluang pengembangan wilayah desa yang optimal (Dryjska dan Beba, 2018). Pemerintah kabupaten Banyuwangi memiliki peran penting dalam membantu pemerintah desa untuk mengembangkan wilayahnya dengan optimal melalui pengelolaan keuangan yang baik. Peran tersebut diwujudkan dengan diterapkannya aplikasi keuangan desa yaitu E-Village Budgeting. Aplikasi ini berbasis website dan bersifat real-time. Aplikasi ini juga terintegrasi antara desa, kecamatan dan dinas-dinas terkait pengelolaan keuangan desa.

Pada tahun 2019 ini, 189 desa di kabupaten Banyuwangi telah menggunakan EVB dalam pengelolaan keuangannya. Berikut kronologi penerapan EVB menurut Burhan salah satu pegawai DPMD Banyuwangi :

2015 kan lahirnya EVB jadi desa-desa dilatih dulu diundang kesini, ada pelatihan tentang EVB. 2016 hanya diwajibkan 
perencanaan saja. Dilatih perencanaannya seperti apa. Akhir 2016 dilatih penatausahaan. 2017 diwajibkan penatausahaan. 2018 wajib sетиа perencanaan, penatausahaan dan pelaporan. Serentak ke semua 189 desa. Tidak ada pilot project tapi serentak.

Selain E-Village Budgeting di Kabupaten Banyuwangi, penerapan sistem keuangan desa atau SISKEUDES dilakukan diberbagai daerah berdasarkan nota kesepahaman antara Menteri Dalam Negeri bersama Kepala Badan Pengawasan Keuangan Pembangunan Nomor 9001627115J dan MOU-16/I(D412015) tentang pengelolaan keuangan desa. Aplikasi ini merupakan aplikasi sederhana yang dikembangkan Badan Pengawasan Keuangan dan Pembangunan (BPKP) bersama Ditjen Bina Pemerintahan Desa Kementerian Dalam Negeri. Aplikasi ini dikembangkan dalam rangka meningkatkan kualitas tata kelola keuangan desa. Fiturfitur yang ada dalam aplikasi Siskeudes dibuat sederhana dan user friendly sehingga memudahkan pengguna dalam mengoperasikan aplikasi Siskeudes. Dengan proses penginputan sekali sesuai dengan transaksi yang ada, dapat menghasilkan output berupa dokumen penatausahaan dan laporan-laporan yang sesuai dengan ketentuan perundangundangan. Tujuan diterapkannya Siskeudes hampir sama dengan E-Village Budgeting yaitu adanya pemberian dana ke desa yang begitu besar, jumlah pelaporan yang beragam serta adanya titik-titik kritis dalam pengelolaan keuangan desa yang menuntut tanggung jawab besar pula oleh aparat Pemerintah Desa (BPKP, 2015).

Menurut wawancara yang telah dilakukan dengan Windi Sindu Pradan, Staff Dinas Komunikasi, Informatika dan Persandian kabupaten Banyuwangi perbedaan EVB dan Siskeudes tidak mengganggu user dalam pengoperasiannya, hanya diperlukan sedikit penyesuaian pada laporan yang diminta oleh BPKP :

BPKP kan minta laporan yang sesuai dg format mereka. Kalo siskeudes kan nggak masalah karena itu diciptakan BPKP. Karena kita pake EVB kita harus menyesuaikan. Tapi gak harus migrasi, hanya saat report saja yg harus disesuaikan dg report mereka.

\section{Indikator Efektivitas Sistem EVB}

Pengukuran efektivitas sistem yang dilakukan adalah dengan menggunakan ISO 9126. ISO 9126 adalah standar internasional yang diterbitkan oleh ISO yang dapat digunakan untuk evaluasi kualitas perangkat lunak dan merupakan pengembangan dari ISO 9001. ISO 9126 memiliki model struktur dan komponen yang lebih jelas dan tidak ambigu dibandingkan model yang lain, sehingga 
tidak menimbulkan kesalahan interpretasi model ataupun kesalahan saat proses evaluasi sistem (Behkamal et al., 2009). Standar ini terdiri dari empat bagian yang menjelaskan model kualitas, metrik eksternal, metrik internal, dan metrik kualitas yang digunakan. Berdasarkan hasil analisis yang telah dilakukan terhadap empat bagian standar, dirumuskan indikator-indikator berikut yang digunakan untuk mengukur efektivitas EVB dalam mencegah fraud pengelolaan keuangan desa yaitu task effectiveness, error frequency, compliance, dan satisfaction.

1. Analisis dan Pembahasan Task Effectivenes

Pengertian task effectiveness menurut ISO 9126 adalah seberapa besar proporsi tujuan dari sebuah tugas sudah dicapai dengan benar. Tugas yang dimaksud dalam EVB adalah tingkat akurasi laporanlaporan keuangan yang dihasilkan berdasarkan entri data yang telah dilakukan. Dengan adanya EVB dapat dihasilkan laporan keuangan yang akurat dengan waktu yang relatif singkat dibandingkan dengan saat sebelum memakai EVB. Berikut pernyataan Yudi Arisona, Kaur Keuangan Desa Cluring mengenai efektivitas EVB dalam menjalankan tugasnya :

Sebelum ada EVB manual mbak, by excel. Misal tahun ini penggunaan apa saja per bidang, satu tahun mau digunakan untukapa sesuai usulan masyarakat, by excel. Kita buat RPD, rencana penggunaan dana. Kalo EVB kita tinggal input nanti RPD nya muncul sendiri tinggal print. EVB kita gak perlu buat kolom dan lain lain, formatnya sudah ada sendiri. Tahap 1 untuk apa semua muncul.

2. Analisis dan Pembahasan Error Frequency Intensitas terjadinya error atau kesalahan saat entry maupun upload data dalam ISO 9126 disebut dengan error frequency. Data yang diinput dalam EVB adalah segala jenis data keuangan dan non keuangan seperti RKPDES, APBDES dan KIP. Berdasarkan penelitian yang telah dilakukan, frekuensi kesalahan yang terjadi tergolong jarang dan kalaupun ada besarnya tidak material. Berikut pendapat Yudi Arisona, Kaur Keuangan Desa Cluring mengenai kesalahan yang pernah terjadi :

Kendalanya itu, kadang kalo di akhir tahun sering lemot soalnya banyak sekali penggunanya. Sistemnya down.

Pernyataan serupa mengenai error system juga disampaikan oleh Makromul Fuadi, Bendahara Desa Alasmalang :

Kadang system itu yang saya tahu, mesti ada saja, penjumlahannya, kita klik runtut tetep error-error. Jadi kita ya harus sabra mengikuti alurnya. Kadang kita nge-save nggak cukup sekali. Laporan pajak atau apa nggak cukup sekali. Kadang kita save sekali masih error, jadi coba lagi dan lagi.

\footnotetext{
67 E-VILLAGE BUDGETING : EFEKTIVITAS PENCEGAHAN FRAUD PADA PENGELOLAAN KEUANGAN DESA DI KABUPATEN 
Kedua pendapat diatas sedikit berbeda dari Rika Dian Puspita, Kaur Keuangan Desa Ketapang yang menyatakan bahwa system EVB sudah berjalan lancar dan tidak terjadi error :

EVB lancar. Karena kan yang pakai bukan cuma desa, SKPD terkait juga pakai. DPMD, BPKAD, Inspektorat. Mereka semua bisa akses. Makanya kalo ada error langsung segera ditangani. Terintegrasi.

\section{Analisis dan Pembahasan Compliance}

Compliance dalam ISO 9126 merujuk pada seperangkat atribut untuk menilai kelayakan apakah perangkat lunak telah memenuhi standardisasi, konvensi atau peraturan organisasi/pemerintah dalam kaitannya dengan efisiensi. Peraturan pemerintah yang menjadi pedoman pengelolaan keuangan desa adalah Peraturan Menteri Dalam Negeri No. 113 tentang Pengelolaan Keuangan Desa. Oleh karena itu system EVB harus mampu mempermudah perangkat desa dalam mengelola keuangan sesuai dengan peraturan yang berlaku.

Yudi Arisona menyatakan bahwa EVB telah efektif dalam membantu perangkat desa dalam mengelola keuangan sesuai dengan peraturan yang sedang berlaku saat ini :

Iya sangat terbantu. Karena disini kan kelihatan. Digunakan untuk pembangunan, pemberdayaan, bedah rumah, penanggulangan kemiskinan. Dalam bidang pemberdayaan, pembangunan. Tergantung prioritas penggunaan dana (berdasarkan peraturan) untuk apa.

4. Analisis dan Pembahasan Satisfaction

Satisfaction atau kepuasan dalam ISO 9126 didefinisikan sebagai kemampuan perangkat lunak untuk memuaskan pengguna dalam konteks penggunaan tertentu. Kepuasan pengguna sangat dipengaruhi oleh "quality in use" dari sistem itu sendiri. Kepuasan pengguna juga dipengaruhi kualitas eksternal sistemnya (Jung, 2007). Pada indikator ini dibahas mengenai kelebihan dan kekurangan EVB serta pendapat pengguna mengenai system EVB yang telah berjaan saat ini.

Berikut pernyataan Yudi Arisona terkait kepuasannya sebagai pengguna EVB :

Dengan adanya EVB jadi lebih mudah dalam pengelolaan keuangan desa. Yang kedua controlling penggunaan dananya sangat bagus. Misalnya ada yang belum saya input, kok kurang APBDes-nya, nanti bisa dicek disitu. Di EVB sini, sistem transparansinya juga bagus, bisa dilihat masyarakat lewat website desa.banyuwangikab.go.id

Begitupula yang dikatakan oleh Makromul Fuadi, Kaur Keuangan Desa Alasmalang :

EVB lebih membantulah kegiatan, misal ada permintaan data laporan kita gak perlu repot mencari file-file, kadang kita nyari di 
computer ilang. Kalo disini ada rekapnya,

tinggal download trus print.

69 E-VILLAGE BUDGETING : EFEKTIVITAS PENCEGAHAN FRAUD PADA PENGELOLAAN KEUANGAN DESA DI KABUPATEN BANYUWANGI

Anak Agung Gde Satia Utama

Afika Rana Zahari

Universitas Airlangga 



\section{Tabel 4}

Rangkuman Hasil Wawancara

\begin{tabular}{|c|c|c|c|c|c|}
\hline \multirow{2}{*}{ No } & \multirow{2}{*}{$\begin{array}{l}\text { Sumber } \\
\text { Data }\end{array}$} & \multirow{2}{*}{ Indikator } & \multirow{2}{*}{ Konten } & \multicolumn{2}{|c|}{ Efektivitas } \\
\hline & & & & Yes & No \\
\hline \multirow[t]{2}{*}{1} & \multirow[t]{2}{*}{$\begin{array}{l}\text { Wawancar } \\
\text { a }\end{array}$} & \multirow[t]{2}{*}{$\begin{array}{c}\text { Task } \\
\text { Effectivenes } \\
s\end{array}$} & $\begin{array}{l}\text { - Kalo EVB kita tinggal input nanti RPD nya muncul sendiri tinggal print. EVB kita gak } \\
\text { perlu buat kolom dan lain lain, formatnya sudah ada sendiri. Tahap } 1 \text { untuk apa semua } \\
\text { muncul. } \\
\text { - Kalo penggunaan evb ini sangat efektiflah. Karena membantu kami melakukan } \\
\text { perencanaan untuk tahun itu. Membantu pemerintah desa. Kalo gaada evb kita pake } \\
\text { manual, otomatis selain waktu, lemot, molor, kalo evb kan cepet, efisien waktu, efisien } \\
\text { tenaga kerja (Yudi Arisona, Bendahara Desa Cluring). }\end{array}$ & $\mathbf{V}$ & \\
\hline & & & $\begin{array}{l}\text { Iya. Kalo sistem ini ndak mikir sudah, akurat, nge-link sendiri ke laporan laporan itu. } \\
\text { Kalo kita masih manual kita nggarap buku kas umum anggaran ini-itu........ Kalo EVB } \\
\text { ini klik satu kali sudah link ke semuanya. Hemat waktu (Habib, Plt. Sekretaris Desa } \\
\text { Kedayunan) }\end{array}$ & $\mathbf{V}$ & \\
\hline \multirow[b]{2}{*}{2} & \multirow[b]{2}{*}{$\begin{array}{l}\text { Wawancar } \\
\text { a }\end{array}$} & \multirow[b]{2}{*}{$\begin{array}{l}\text { Error } \\
\text { Frequency }\end{array}$} & $\begin{array}{l}\text { Kendalanya itu, kadang kalo di akhir tahun sering lemot soalnya banyak sekali } \\
\text { penggunanya. Sistemnya down. (Yudi Arisona, Bendahara Desa Cluring). }\end{array}$ & $\mathbf{V}$ & \\
\hline & & & $\begin{array}{l}\text { Kadang system itu yang saya tahu, mesti ada saja, penjumlahannya, kita klik runtut tetep } \\
\text { error-error. Jadi kita ya harus sabra mengikuti alurnya. Kadang kita nge-save nggak cukup } \\
\text { sekali. Laporan pajak atau apa nggak cukup sekali. Kadang kita save sekali masih error, } \\
\text { jadi coba lagi dan lagi. (Makromul Fuadi, Bendahara Desa Alasmalang) }\end{array}$ & & $\mathbf{V}$ \\
\hline
\end{tabular}


Enggak. EVB lancar. Karena kan yg makai bukan cuma desa, SKPD terkait juga pakai.

DPMD, BPKAD, Inspektorat. Mereka semua bisa akses. Makanya kalo ada error langsung

segera ditangani. Terintegrasi (Rika Dian Puspita, Bendahara Desa Ketapang).

Iya sangat terbantu. Karena disini kan kelihatan. Digunakan untuk pembangunan,

pemberdayaan, bedah rumah, penanggulangan kemiskinan. Dalam bidang pemberdayaan,

Wawancar

pembangunan. Tergantung prioritas penggunaan dana (berdasarkan peraturan) untuk apa.

V

Compliance

(Yudi Arisona, Bendahara Desa Cluring)

Iya. Sangat membantu (menaati peraturan pemerintah). Nggak terlalu pusing. (Habib, Plt. Sekretaris Desa Kedayunan).

Dengan adanya EVB jadi lebih mudah dalam pengelolaan keuangan desa. Yang kedua controlling penggunaan dananya sangat bagus. Misalnya ada yang belum saya input, kok kurang APBDes-nya, nanti bisa dicek disitu. Di EVB sini, sistem transparansinya juga bagus, bisa dilihat masyarakat lewat website desa.banyuwangikab.go.id. (Yudi Arisona, Bendahara Desa Cluring)

Kalo kelebihannya ya lebih membantu lah kegiatan, misal ada permintaan data laporan kita gak perlu repot mencari di file lain, kadang kita nyari di komputer ilang. Kalo disini ada rekapnya tinggal download trus print (Makromul Fuadi, Bendahara Desa Alasmalang)

Ya enakan ini mbak. Jadi habis masukan satu item yaudah, kalo pake excel kan nggak. Satu entry an udah nyebar kemana mana. Kita tinggal download aja sudah. Kalo sungkan download, cetak langsung bisa (Habib, Plt. Sekretaris Desa Kedayunan).

- Udah pas. Udah sesuai. Udah amat sangat mudah diaplikasikan, mudah untuk kita buat laporan, lebih mudah dari yg buatan pemerintah pusat. Siskeudes terlalu general nggak detail, akhirnya yang masukin juga bingung karena terpaku sama permen aja

- Kita lebih detail. Kalo dimintai laporan, pake EVB udah diterima dengan sangat baik. Malah lebih diacungi jempol. Kita juga lebih dulu menerapkannya (dibanding Siskeudes). Siskeudes masih offline, kita udah online. EVB sudah terinci per rekening, 
siskeudes belum, bahkan (EVB) ada sub rekeningnya (Rika Dian Puspita, Bendahara

Desa Ketapang).

Sumber : Olahan, 2019 
Efektivitas EVB dalam Mencegah Fraud Pengelolaan Keuangan Desa

Besarnya dana yang turun bagi desa saat ini dapat menjadi sebuah peluang sekaligus tantangan bagi pemerintah desa. Peluang yang timbul adalah desa dapat lebih maksimal dalam melakukan pembangunan maupun pengembangan masyarakat tanpa terkendala dana, namun tantangannya adalah pemerintah desa dituntut untuk memberikan akuntabilitas dan transparansi sebaik mungkin dalam mengelola dana. Dana yang besar ini pula dapat berpotensi menimbulkan kecurangan dalam pengelolaan keuangan. Menurut Tarjo dan Herawati (2015), kecurangan keuangan ini adalah yang paling berbahaya dibandingkan dua yang lain, yaitu korupsi dan penyalahgunaan asset.

Menghadapi hal tersebut Pemerintah Kabupaten Banyuwangi pada tahun 2016 telah menyiapkan EVB sebagai alat bantu dalam pengelolaan keuangan desa sehingga dana dapat dikelola dengan akurat, efektif dan efisien. Hal ini disampaikan oleh Windi Sindu Pradan, S. Kom., Staff Bagian Umum dan Keuangan Diskominfo Kabupaten Banyuwangi :

Selama ini kan pemerintah menggelontorkan banyak dana. Kekhawatiran pemerintah adalah sdm yang di desa kalo di lepas begitu aja tanpa ada pendampingan menggunakan sistem ditakutkan nanti berujung penyalahgunaan sebenarnya karena ketidaktahuan. Dengan adanya aplikasi evb ini, diharapkan petugas yang aada di desa dalam mengelola keuangan desa bisa lebih tepat, sehingga penyalahgunaan dalam tanda kutip akibat ketidaktahuan ini dapat dihindari atau diminimalkan.

Dalam penerapannya, pemerintah desa merasa system EVB saat ini telah efektif dalam mencegah kecurangan. Hal ini dikarenakan EVB memiliki satu mekanisme berbeda dengan saat masih manual yaitu pada proses pencairan dananya. Hal ini disampaikan oleh Habib, Plt. Sekretaris Desa Kedayunan :

Kalo dijaman sebelum EVB, kita penarikan uangnya per paket, satu titik bangunan pavingisasi butuh dana $50 \mathrm{jt}$, itu di tarik sekaligus $50 \mathrm{jt}$. Jadi uang di bendahara 50 jt. Kalo EVB ndak, penarikannya per kebutuhan. Sesuai SPP. Ada satu paket $50 \mathrm{jt}$, hari ini beli paving 10 jt, kita entry SPP ya ambil uang 10 jt itu tok. Ndak global. Uang langsung kita setorkan ke rekanan.

Dengan adanya mekanisme tersebut, pengelolaan keuangan desa menjadi lebih transparan, aman dan mudah dalam pengawasannya. Mekanisme tersebut tertuang dalam flowchart berikut ini : 


\section{Gambar 1}

\section{Mekanisme Pencairan Dana Kegiatan dalam EVB}

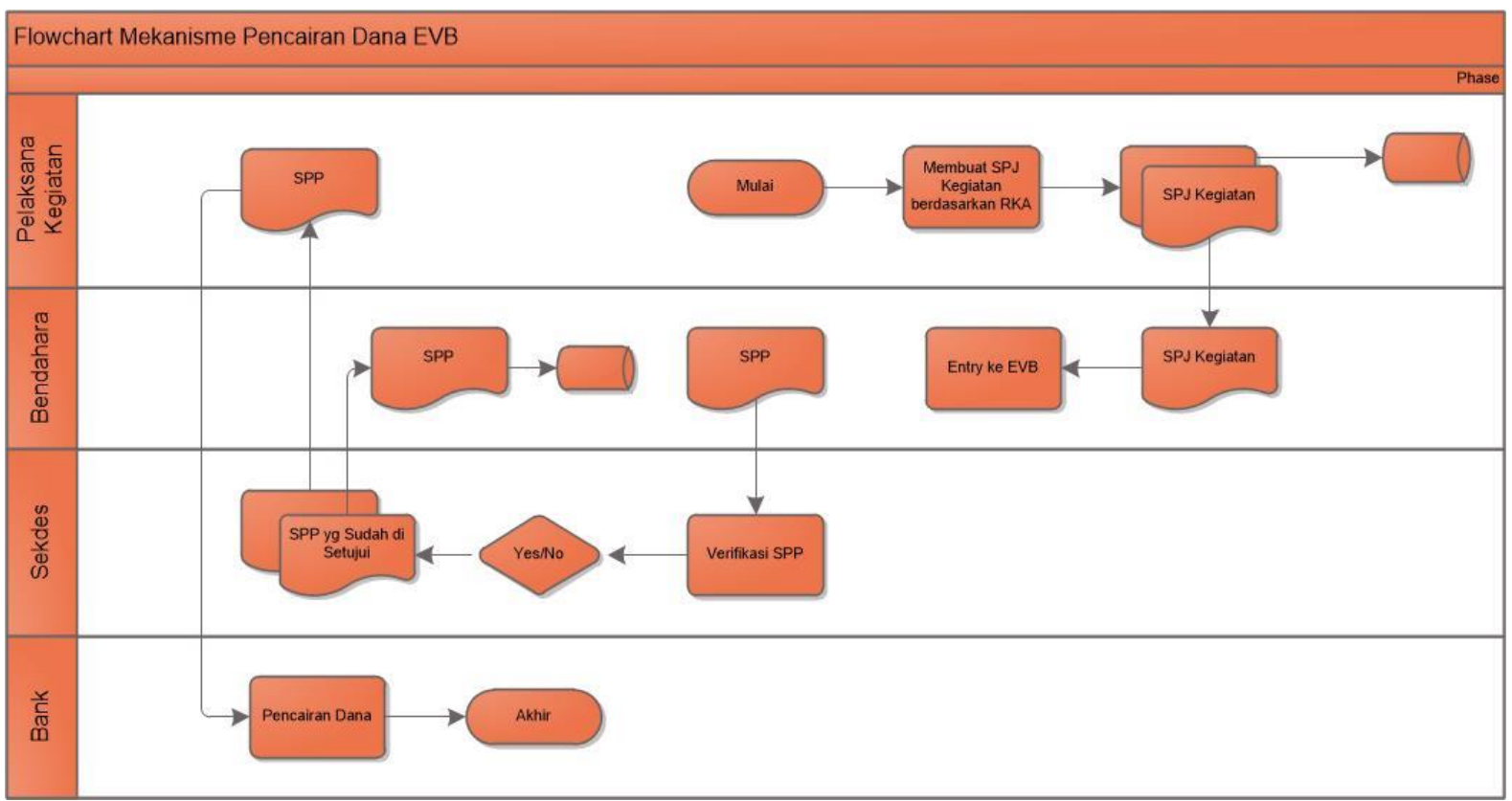

\section{Sumber : Olahan, 2019}

Saat ini, dalam proses pencairan dana, peran sekretaris desa lebih dioptimalkan oleh pemerintah kabupaten Banyuwangi yaitu sebagai verifikator, setiap dana yang keluar pasti sudah atas persetujuan Sekdes, tidak hanya diketahui oleh bendahara desa saja. Ketika cukup banyak pihak yang terlibat maka kemungkinan terjadinya kecurangan juga minimal. Sistem pengendalian internal yang kuat dan penetuan peran serta tanggungjawab dari semua pihak terkait sangat dibutuhkan dalam mencegah dan mendeteksi kecurangan (Zager et al., 2016).

Rika Dian Puspita, Bendahara Desa Ketapang mengakui bahwa system EVB saat ini telah efektif dalam mencegah kecurangan dalam pengelolaan keuangan yang mungkin terjadi. Berikut pernyataannya :

Kecurangan terjadi itu kan karena beberapa faktor. Kalo dari segi personal ya kembali ke individunya ya. Tapi kalo dari segi akuntabel dan transparansinya dia sudah amat sangat akuntabel dan transparan. Karena semua bisa mengakses, SKPD terkait. Kita gak bisa utek-utek kalo udah jadi entry an data. Apalagi ketika udah dikunci, di lock sama dinas terkait, kita udah gak bisa ngapa ngapain lagi, mau ngeles ngeles kemana. 


\section{KESIMPULAN DAN SARAN}

Electronic Village Budgeting merupakan sistem aplikasi pengelolaan keuangan yang telah efektif dalam membantu desa mengelola aspek keuangan dengan sangat baik. Sistem EVB memiliki prosedur yang user friendly sehingga mudah dioperasikan oleh pemerintah desa. Selain itu EVB juga memudahkan pengawasan oleh Inspektorat karena sistemnya yang online dan terintegrasi. EVB telah berhasil membantu desa mengelola keuangan desa dengan efektif dan efisien. Desa juga tidak kesulitan melakukan fungsi transparansi dan akuntabilitas dalam pengelolaan keuangan.

Penelitian ini juga memiliki keterbatasan karena belum pernah ditemukan kecurangan yang material dalam pengelolaan keuangan selama EVB dipakai, sehingga peneliti belum sepenuhnya dapat membuktikan efektivitas system EVB dalam mencegah kecurangan yang terjadi.

Dalam penelitian berikutnya diperlukan indikator yang lebih akurat dan mudah diaplikasikan untuk mengukur efektivitas sebuah sistem atau perangkat lunak. Sehingga kesimpulan yang dihasilkan bisa memiliki tingkat validitas yang tinggi.

\section{DAFTAR PUSTAKA}

Attigeri, Girija et al. 2018. Knowledge Base Ontology Building for Fraud Detection Using Topic Modelling. Procedia - Computer Science 135.

Ayu, Putu Desiana Wulaning. 2017. Analisis Pengukuran Tingkat Efektivitas dan Efisiensi Sistem Informasi Manajemen Surat STIKOM Bali. Jurnal Sistem dan Informatika : Vol 11, No. 2

Badan Pengawasan Keuangan dan Pembangunan. 2015. Leaflet Sistem Keuangan Desa. bpkp.go.id

Behkamal, Behshid et al. 2009. Customizing ISO 9126 Quality Modl for Evaluation B2B Applications. Elsevier - Information and Software Technology 51.

Bodnar, George $\mathrm{H}$ dan William S. Hopwood. 2013. Accounting Information Systems, Eleventh Edition. New Jersey : Pearson Ed. Prentice Hall

Chouiekh, Alae dan E.H.I El Haj. 2018. ConvNets for Fraud Detection Analysis. Procedia - Computer Science 127.

Cresswell, J. W. 2014. Research Design (fourth). Los Angeles: SAGE Publications.

Dryjska, Ewa Kiryluk dan Patrycja Beba. 2018. Regional Specific Budgeting of Rural Development Funds - An Application Study. Elsevier - Land Use Policy : 77.

Gelinas, Ulric. J, Richard B. Dull. 2008. Accounting Information Systems, 7th Edition. USA : Thompson Corporation.

International Organization for Standardization. 2009. International Standard ISO/IEC 9126 : Software Engineering-Product Quality

Jung, Ho-Won. 2007. Validating The External Quality Subcaracteristics of Software Products According to ISO/IEC 9126. Computer Standards and Interfaces 29 
Kabupaten Banyuwangi. 2017. E-Village Budgeting Banyuwangi Masuk Top 40 Inovasi Pelayanan Publik 2017. https://www.banyuwangikab.go.id/b erita-daerah/e-village-budgetingbanyuwangi-masuk-top-40-inovasipelayanan-publik-2017.html (diakses pada 21 September 2018 pukul 06.15)

Kementerian Dalam Negeri. 2014. Peraturan Menteri Dalam Negeri No. 13 tentang Desa

Lokanan, Mark. E. 2015. Challenges to the Fraud Triangle : Questions on its Usefulness. Elsevier Accounting Forum-315 pg 24

Morales, Jeremy et al. 2014. The Costruction of the Risky Individual and Vigilant Organization : A Genealogy of the Fraud Triangle. Elsevier - Accounting, Organization and Society.

Munfarida et al. 2018. Pengelolaan Keuangan Desa melalui E-Village Budgeting di Kabupaten Banyuwangi. e-Journal Ekonomi Bisnis dan Akuntansi, 2018, Volume V (1) : 105-108

Neuman, W.Lawrence. 2014. Social Research Methods : Qualitative and Quantitative Approaches 7th Edition. London : Pearson International

Pratiwi, Ratih Nur. 2016. Manajemen Keuangan Desa Melalui Inovasi Electronic Village Budgeting (Studi pada Badan Pemberdayaan Masyarakat dan Pemerintahan Desa Kabupaten Banyuwangi). Jurnal
Ilmiah Administrasi Publik Vol. 2, No. 3, pp 123-130

Rahman, Rashidah Abdul., dan I. S. K. Anwar. 2014. Effectiveness of Fraud Prevention and Detection Techniques in Malaysian Islmaic Banks. Procedia - Social and Behavioral Science 145

Romney, Marshall B. and Paul J. Steinbart. 2017. Accounting Information System : $14^{\text {th }}$ Ed. USA : Pearson.

Rubasundram, Geetha. A. 2015. Perceived "Tone from the Top During A Fraud Risk Assessment. Procedia Economics and Finance 28.

Setyawan, Supanji et. al. 2017. Development Model of E-Budgeting and E-Reporting System on the Management of Village Fund Finance. Jurnal Dinamika Akuntansi Vol. 9, No. 1, March 2017, pp. 92-99

Sukoco, Agus. 2010. Penggunaan Standard ISO 9126 untuk Mengevaluasi Keefektifan Perangkat Lunak. Jurnal Sistem Informasi dan Telematika Vol 1 (No.01).

Tarjo, dan Nurul Herawati. 2015. Application of Beneish M-Score Models and Data Mining to Detect Financial Fraud. Procedia - Social and Behavioral Science 211.

Undang-Undang Nomor 23 Tahun 2014 tentang Pemerintah Daerah

Zager, Lajos et al. 2016. The Role and Responsibilities of Auditors in Preventin and Detection of Farudulent Financial Reporting. Procedia - Economics and Finance 39 